\title{
OPEN Ocean acidification modifies biomolecule composition in organic matter through complex interactions
}

\author{
Julia Grosse ${ }^{\bowtie}$, Sonja Endres \& Anja Engel
}

The main source of marine organic carbon $(\mathrm{OC})$ is autotrophic production, while heterotrophic degradation is its main sink. Increased anthropogenic $\mathrm{CO}_{2}$ release leads to ocean acidification and is expected to alter phytoplankton community composition, primary production rates and bacterial degradation processes in the coming decades with potential consequences for dissolved and particulate $\mathrm{OC}$ concentration and composition. Here we investigate effects of increased $p \mathrm{CO}_{2}$ on dissolved and particulate amino acids (AA) and carbohydrates (CHO), in arctic and sub-arctic planktonic communities in two large-scale mesocosm experiments. Dissolved AA concentrations responded to $p \mathrm{CO}_{2} / \mathrm{pH}$ changes during early bloom phases but did not show many changes after nutrient addition. A clear positive correlation in particulate AA was detected in post-bloom phases. Direct responses in $\mathrm{CHO}$ concentrations to changing $p \mathrm{CO}_{2} / \mathrm{pH}$ were lacking, suggesting that observed changes were rather indirect and dependent on the phytoplankton community composition. The relative composition of AA and $\mathrm{CHO}$ did not change as a direct consequence of $p \mathrm{CO}_{2}$ increase. Changes between bloom phases were associated with the prevailing nutrient status. Our results suggest that biomolecule composition will change under future ocean conditions but responses are highly complex, and seem to be dependent on many factors including bloom phase and sampling site.

The increase in atmospheric carbon dioxide $\left(\mathrm{CO}_{2}\right)$ concentration due to anthropogenic emissions is changing the ocean's carbonate chemistry ${ }^{1}$, leading to ocean acidification. As a consequence, the $\mathrm{pH}$ of ocean waters has decreased by about 0.1 units since 1900 and is predicted to drop by another $0.3-0.5$ units until 2100, with Arctic waters being impacted highest ${ }^{2}$. Ocean acidification promotes the uptake of inorganic carbon by phytoplankton leading to higher primary production rates, and can subsequently result in an increased release of dissolved organic matter $(\mathrm{DOM})^{3-5}$. The molecular composition of marine DOM is highly complex, changes with depth, season, and region ${ }^{6}$, and only a few compounds can be identified in terms of structure by chemical analysis. These compounds include labile and semi-labile components, such as carbohydrates (CHO), amino acids (AA), proteins, peptides, lipids, and nucleic acids, all of which are enriched in freshly produced $\mathrm{DOM}^{6-8}$. In total, up to $90 \%$ of the DOM produced during photosynthesis is degraded by heterotrophic bacteria in the water column, transformed into bacterial biomass or respired to inorganic carbon which potentially feeds back in atmospheric $\mathrm{CO}_{2}$ concentrations ${ }^{9-11}$.

Studies investigating the effects of increasing $\mathrm{pCO}_{2} /$ decreasing $\mathrm{pH}$ on DOM dynamics show a wide range of responses. In several studies no significant changes were detected in dissolved organic carbon (DOC) and other DOM compound concentrations ${ }^{12-14}$. Some studies found significant changes in DOC concentration but the responses were opposite. While two studies in the Arctic and Finland, led by Engel et al. and Paul et al., detected DOC accumulation under very high $p \mathrm{CO}_{2}$ levels ${ }^{3,15}$, Yoshimura et al. ${ }^{16}$ detected increased DOC removal rates under increased $\mathrm{CO}_{2}$ in the Sea of Okhotsk.

AA account for a small fraction (of 1-3\%) of the ocean DOC pool $^{6}$, but they are essential for growth of higher organisms and can either be directly incorporated into the biomass or be used as pre-cursors for the synthesis of more complex $\mathrm{AA}^{17,18}$. CHO contribute between 10 and 25\% to the DOC pool ${ }^{6}$ and are also a primary energy source for heterotrophic bacteria ${ }^{19}$. Additionally, dissolved AA and $\mathrm{CHO}$ are primary building blocks for the formation of more complex marine gel-like particles, an important fraction of the particulate OM pool in the ocean ${ }^{20}$. These particles provide a surface for bacteria to attach and grow, and can become hotspots of microbial 
degradation ${ }^{21,22}$ while also adsorbing large amounts of nutrients ${ }^{23,24}$ and fostering export of organic and inorganic matter ${ }^{20}$. Two forms of gel-like particles can be distinguished by staining methods: (1) Transparent exopolymer particles (TEP) are rich in CHO and are stained with Alcian Blue ${ }^{21}$ and (2) Commassie Stainable Particles (CSP) are stained with Commassie Blue and are characterized by a higher content of $\mathrm{AA}^{23}$.

Ocean acidification may also affect formation and concentration of these gel-like particles and hence the AA and $\mathrm{CHO}$ signal in the total or particulate AA and CHO fraction. The amount of TEP was shown to increase with $p \mathrm{CO}_{2}$ in studies by Endres et al. and MacGilchrist ${ }^{25,26}$. Another study found AA accumulation was slightly decreased at elevated $p \mathrm{CO}_{2}{ }^{12}$, but investigations into CSP changes have not yet occurred. While some efforts were made to determine effects of ocean acidification on gel-like particles, there is no study, to our knowledge, that has investigated compositional changes of individual AA and $\mathrm{CHO}$ in plankton communities exposed to ocean acidification.

Here we show results from two large off-shore mesocosm campaigns conducted in Arctic Kongsfjorden, Svalbard Archipelago, Norway in $2010^{27}$ and Sub-arctic Raunefjord near Bergen, Norway in $2011^{28}$. The Svalbard study manipulated nutrient-poor, post-bloom fjord water dominated by haptophytes and prasinophytes with only minor contributions of diatoms. There the $p \mathrm{CO}_{2}$ levels were increased from $\sim 180$ to $270-1420 \mu \mathrm{atm}^{27}$. The Bergen community was dominated by diatoms, with some chlorophytes, cryptophytes and haptophytes, reflecting a composition more common during the spring bloom. There $p \mathrm{CO}_{2}$ levels were increased from 310 to $395-3045 \mu \mathrm{atm}^{28}$.

For both studies, we investigated changes of AA and $\mathrm{CHO}$ composition in the natural plankton communities as a response to $p \mathrm{CO}_{2}$-induced changes in $\mathrm{pH}$. We hypothesize that $p \mathrm{CO}_{2}$ increase will affect the production and subsequent release of $\mathrm{AA}$ and $\mathrm{CHO}$ by phytoplankton and leave a measurable trace in the water-column. We expect to see changes in absolute pool concentrations as well as in the compound specific composition of the different pools. The changes will differ between bloom phases and nutrient availability (before and after nutrient addition).

Both campaigns were separated into two stages; during the first stage $p \mathrm{CO}_{2}$ levels were manipulated, while during a second phase all mesocosms additionally received a resupply of inorganic nutrients. Based on chlorophyll $a$ development during both campaigns other publications identified distinct bloom-phases within the two stages, which we continued to use for the analysis of our data ${ }^{27,28}$. A first phytoplankton bloom developed after $\mathrm{CO}_{2}$ addition during both campaigns. A second bloom developed after nutrients addition, about halfway through the sampling period. A third phytoplankton bloom developed in Kongsfjorden/Svalbard. Clear postbloom phases were identified in the Raunefjord/Bergen (low phytoplankton biomass after depletion of at least one inorganic nutrient).

\section{Results}

Organic matter development during bloom phases. Development of AA and CHO concentrations (sum of individually measured compounds) in the dissolved (DAA/DCHO) and total fractions (TAA/TCHO) were illustrated in Fig. 1. AA concentrations ranged between 198 and $1998 \mathrm{nM}$ DAA $(\mathrm{n}=315)$ and 365-6241 nM TAA $(\mathrm{n}=313)$ across both campaigns and all bloom phases (including $\mathrm{CO}_{2}$ addition phase). DAA contributed to TAA with $42 \pm 11 \%$ (average \pm stdev, $n=311$, Fig. 1$)$. The remaining $58 \pm 11 \%(n=311)$ are hereafter referred to as particulate AA (PAA).

CHO concentrations ranged between 153 and $5846 \mathrm{nM} \mathrm{DCHO}(\mathrm{n}=294)$ and 477-11,882 nM TCHO $(\mathrm{n}=279)$, including all measurements. The contribution of DCHO to TCHO varied greatly within and between experiments and reached $70 \pm 24 \%(n=87$, range 15-100\%) and $45 \pm 19 \%(n=146$, range 9-93\%) in the Rauneford/Bergen and Kongsfjorden/Svalbard campaign, respectively. Contrary to AA, particulate $\mathrm{CHO}$ could not be calculated for many sampling points (see "Material and methods" section for detailed information).

Overall, large inter-daily variations in the compound class concentrations made it difficult to detect responses of the individual mesocosm to changes in $\mathrm{pH}$ based on the concentration data alone. We therefore used an approach to determine the deviation of each mesocosm from the daily average across all mesocosms to identify potential effects of $\mathrm{pH}$ on bulk organic matter constituents. Afterwards, all values from one bloom-phase were averaged for each mesocosm. Figure 2 gives an overview of the results for total DAA, TAA, DCHO and TCHO (sum of individually measured compounds) using this approach. DAA and TAA showed significant correlations with $\mathrm{pH}$ for several bloom and post-bloom phases while no significant relationships were found in DCHO and TCHO. Additionally, responses were found for many individual AA and also for several CHO.

Changes of individual AA. Significant correlations of MD with $\mathrm{pH}$ were found for several individual AA across both campaigns, in DAA and PAA and during several bloom stages (Fig. 3). For example, during Bloom 1 in Raunefjord all DAA (except Val) were correlated with $\mathrm{pH}$ in a positive binomial function. This means that AA concentrations decreased with decreasing $\mathrm{pH}$ down to 7.72-7.60 ( $\left.p \mathrm{CO}_{2} 890-1165 \mu \mathrm{atm}\right)$, before concentrations increased again with $\mathrm{pH}<7.60\left(\mathrm{CO}_{2}>1165 \mu \mathrm{atm}\right.$, e.g. Fig. $\left.2 \mathrm{~A}\right)$. During Post-Bloom 1 this picture reversed and concentrations of DAA and non-essential AA increased in mesocosms with pH down to 7.72-7.60, and decreased in mesocosms with $\mathrm{pH}<7.60$. Changes in PAA were mainly observed during Post-Bloom phases (Bergen) and were only occasionally found in the Svalbard campaign. PAA during Bloom 1 (Raunefjord/Bergen) showed significant correlations with $\mathrm{pH}$ for the AA Ser, Tyr, Leu, Ile and Phe using a positive binomial function, again with a lowest $\mathrm{MD}$ for mesocosms with $\mathrm{pH} 7.72-7.60$ ( $\mathrm{CO}_{2}$ to $\left.890-1165 \mu \mathrm{atm}\right)$. During Post-Bloom 1 (Raunefjord/Bergen) all individual PAA showed significant increases with decreasing $\mathrm{pH}$.

In Kongsfjorden/Svalbard during Bloom 1 significant negative correlations were found with decreasing $\mathrm{pH}$ for AsX, GIX and all essential AA in the DAA fraction, while no significant relationships were found for PAA (Fig. 3). 

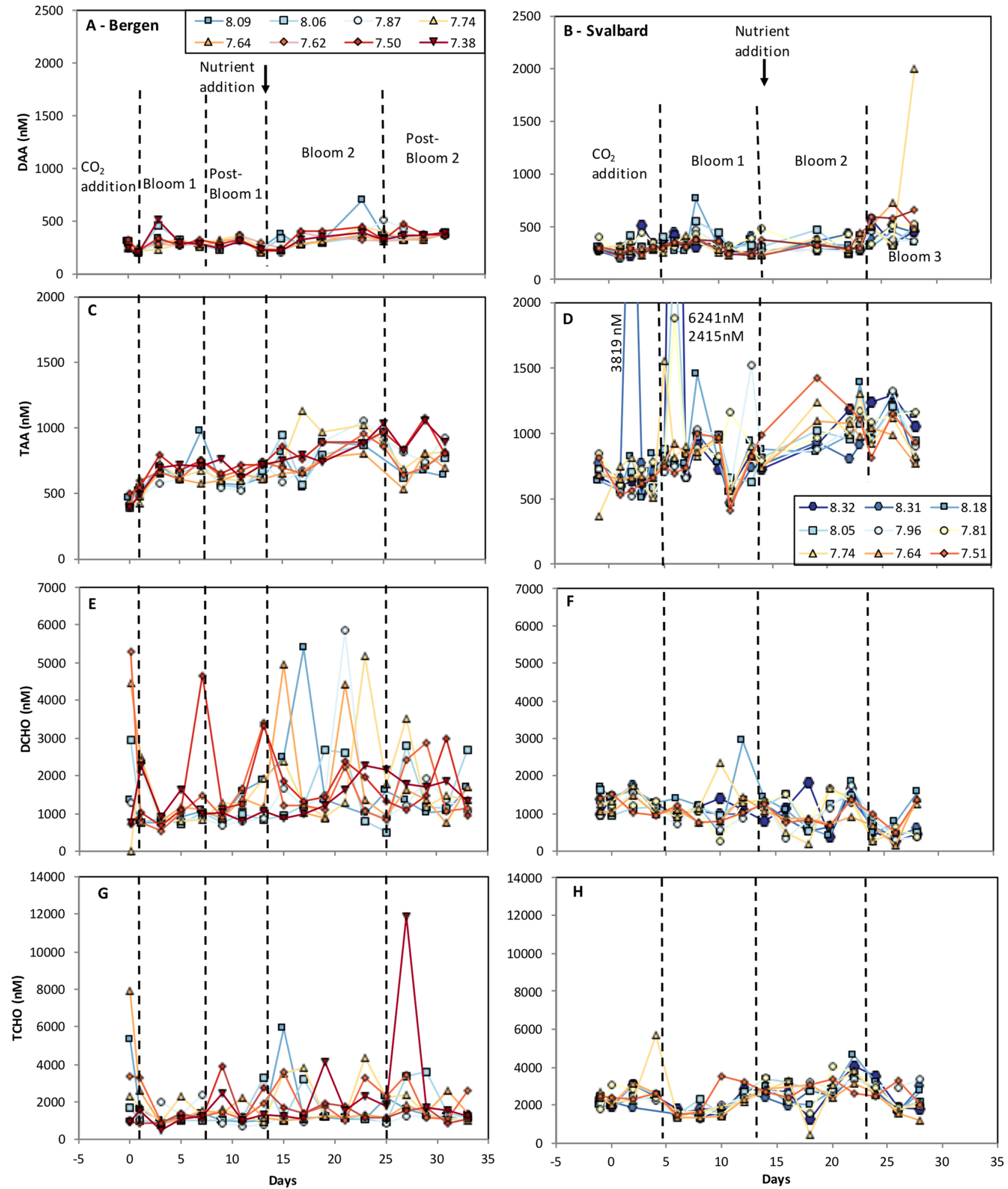

Figure 1. Development of concentrations of dissolved and total amino acids (A-D) and dissolved and total carbohydrates (E-H) for all mesocosms in Raunefjord/Bergen and Kongsfjorden/Svalbard. Numbers in legend refer to initial $\mathrm{pH}$ values of respective mesocosm, also see Table 1.

A few correlations of $\mathrm{MD}$ with $p \mathrm{CO}_{2}$ were also found after nutrient addition. However, they were limited to a few individual compounds such as DAA Phe and Leu in Post-Bloom 2 (Raunefjord/Bergen) and DAA AsX, Ala and multiple essential DAA during Bloom 3 in Kongsfjorden/Svalbard. Within the PAA fraction MD correlated 


\begin{tabular}{|l|l|l|l|l|l|l|l|l|l|l|l|}
\hline \multicolumn{2}{|l|}{ Raunefjord, Bergen } \\
\hline $\mathrm{pCO}_{2}$ & & & 310 & 395 & 590 & & 890 & 1165 & 1425 & 2060 & 3045 \\
\hline $\mathrm{pH}$ & & & 8.13 & 8.04 & 7.88 & & 7.71 & 7.60 & 7.52 & 7.36 & 7.20 \\
\hline & & & & & & & & & & \\
\end{tabular}

Table 1. Initial values of $p \mathrm{CO}_{2}$ and $\mathrm{pH}$ in all mesocosms at day $\mathrm{t}_{5}$ (Bergen) and $\mathrm{t}_{8}$ (Svalbard) when equilibrium of added $\mathrm{CO}_{2}$ with dead space was reached. Same shapes and colors indicate similar levels of ocean acidification reached between campaigns. Symbols and color code denote those in Figs. 1, 2 and S2.
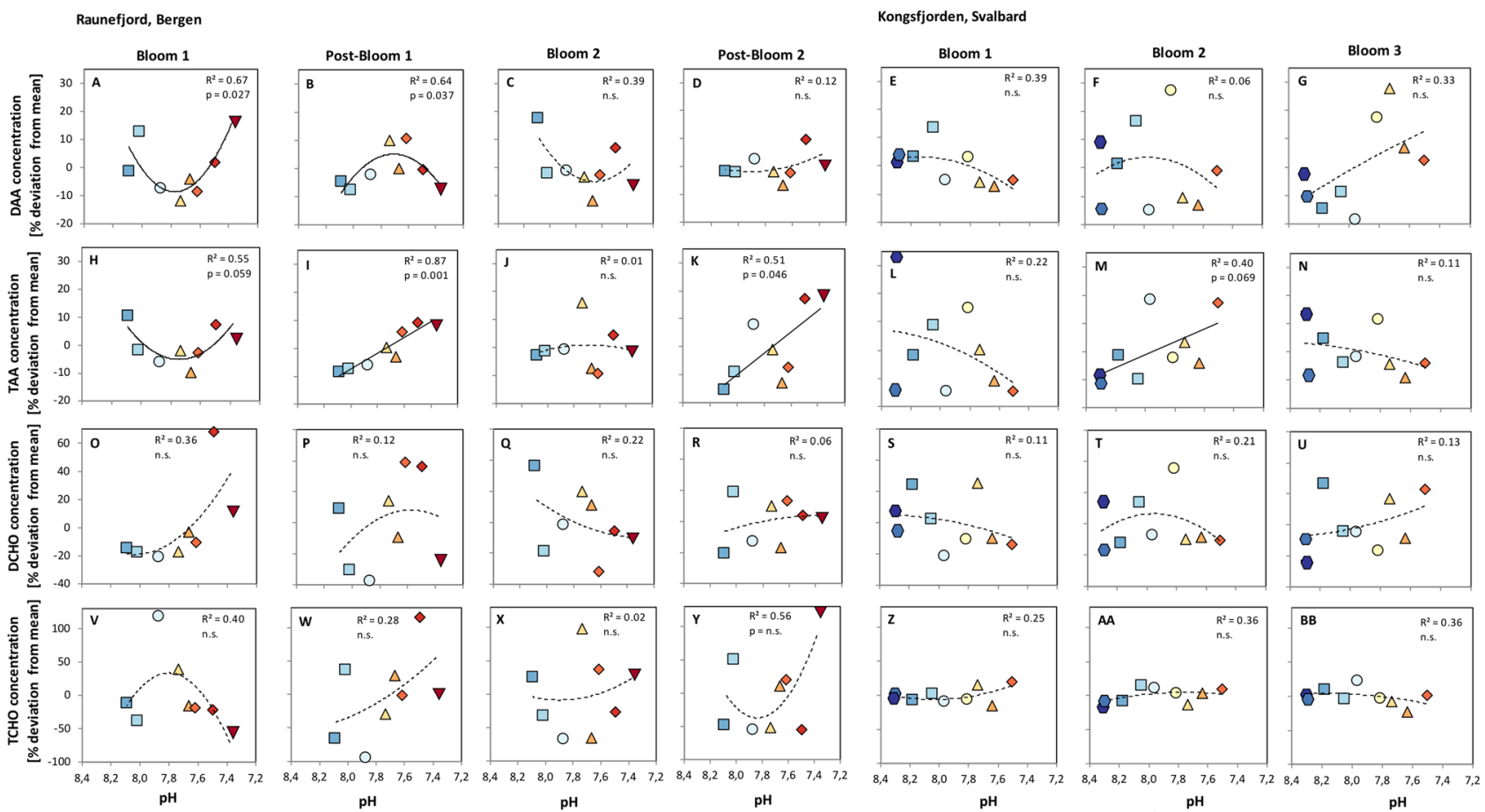

pH

pH

$\mathrm{pH}$

$\mathrm{pH}$

pH

Figure 2. DAA, TAA, DCHO and TCHO concentrations (\%deviation from mean) as a function of decreasing $\mathrm{pH}$ (total scale; increasing $p \mathrm{CO}_{2}$ ). Linear and binomial regressions were performed and significance of trends is stated in each plot. Symbols indicate deviation from mean of all mesocosms over time in different phases of bloom development for both mesocosm campaigns. For symbol identification see Table 1. The bloom phases and time point of nutrient additions were identified by Schulz et al. ${ }^{27,28}$. Dashed lines indicate non-significant relationships. Nutrient additions occurred at the end of Post-Bloom 1 (Raunefjord/Bergen) and between Bloom 1 and Bloom 2 (Kongsfjorden/Svalbard).

positively with decreasing $p \mathrm{CO}_{2}$ for all AA during Post-Bloom 2 (Raunefjord/Bergen) and but only for AsX, Phe, Ile and Leu during Bloom 2 (Kongsfjorden/Svalbard).

Relative changes (mol\%) in AA composition were evaluated using principal component analysis (PCA) for individual AA of DAA and PAA of Bergen and Svalbard experiments, respectively. The first two components (PC1, PC2) explained $44-62 \%$ of the variance in the dataset (Fig. 4). The composition of DAA changed between experimental phases in both campaigns (Fig. 4A,C). In Raunefjord/Bergen the DAA composition during PostBloom 1 was enriched in Ala, Ile and Arg, during Bloom 2 enrichment in AsX was seen and during Post-Bloom 2 Thr was enriched. DAA in Kongsfjorden/Svalbard were enriched in AsX, GIX and Arg during Bloom 1. After nutrient addition, Gly and Ser seemed to be enriched in some mesocosms during Bloom 2 (Fig. 4C). Bloom 3 showed enrichment in the essential AA Val, Ile, Leu, Phe and Thr, as well as non-essential AA Tyr. Changes in the relative composition of PAA were only found in Raunefjord/Bergen (Fig. 4B). There, Bloom 1 showed enrichment in AsX, Arg, Gly and Tyr while Post-Bloom 1 showed enrichment in Ser and GIX. After nutrient 


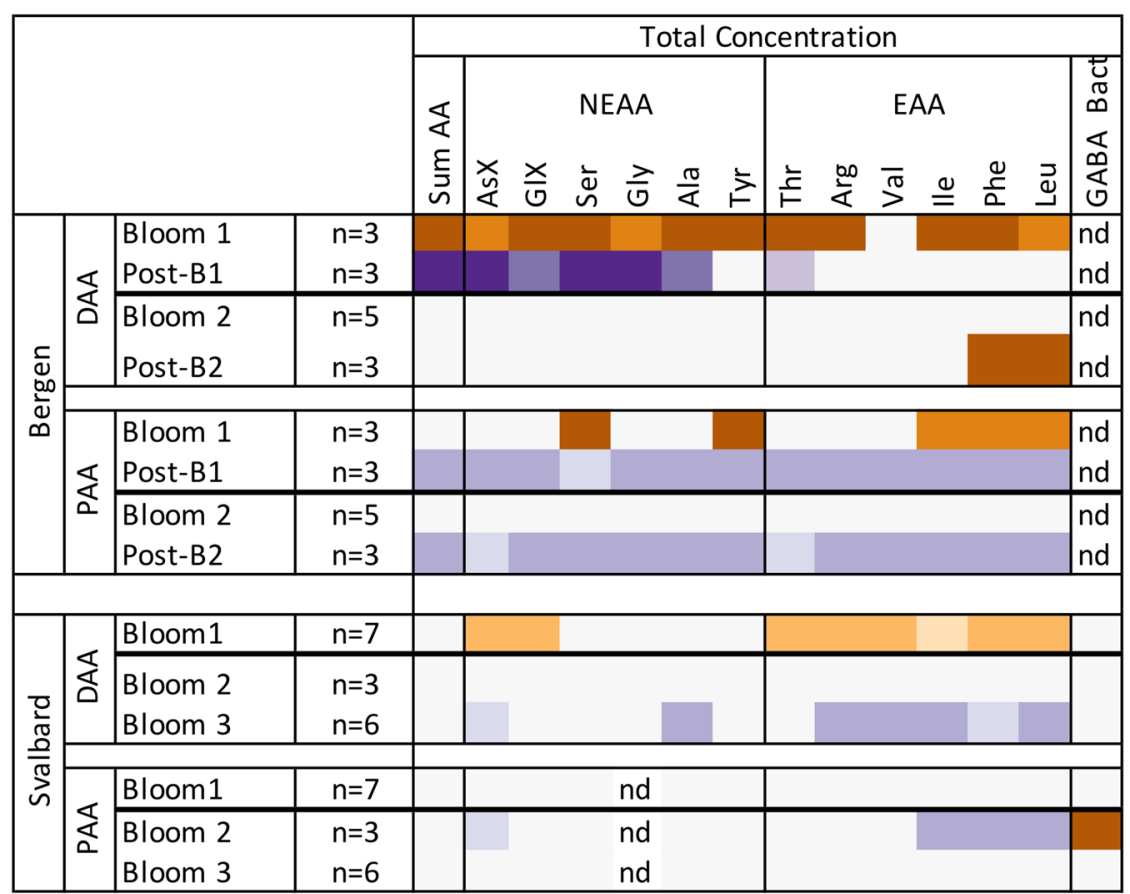

pos. binomial, $p<0.05$ pos. binomial, $0.05<p<0.1$ linear decrease, $0.05<p<0.1$ linear decrease, $\mathrm{p}<0.05$ not significant

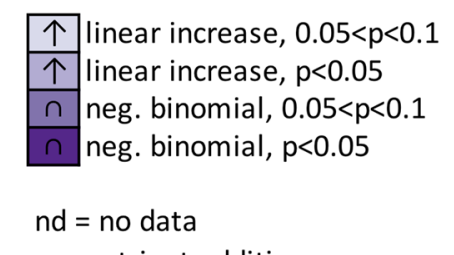

nutrient addition

Figure 3. Heat-map summarizes significance levels for all individual AA (DAA and PAA) as calculated in Fig. 1. Bloom phase-averaged response in mean deviation of concentrations against decreasing $\mathrm{pH}$. Refer to Table 2 for acronyms.

\begin{tabular}{|c|c|c|c|}
\hline \multicolumn{2}{|c|}{ Amino acids } & \multicolumn{2}{|c|}{ Carbohydrates } \\
\hline DAA & Dissolved amino acids & DCHO & Dissolved carbohydrates \\
\hline PAA & Particulate amino acids & TCHO & Total carbohydrates \\
\hline TAA & Total amino acids & Fuc & Fucose \\
\hline NEAA & Non-essential amino acids & Rha & Rhamnose \\
\hline EAA & Essential amino acids & Ara & Arabinose \\
\hline AsX & Asparagine + aspartic acid & Gal & Galactose \\
\hline GlX & Glutamine + glutamic acid & Glc & Glucose \\
\hline Ser & Serine & ManXyl & Mannose/xylose \\
\hline Gly & Glycine & GalN & Galactosamine \\
\hline Ala & Alanine & GlcN & Glucosamine \\
\hline Thr & Threonine & GlcA & Gluconic acid \\
\hline Tyr & Tyrosine & GalUA & Galacturonic acid \\
\hline Arg & Arginine & GlcUA & Glucuronic acid \\
\hline Val & Valine & MurA & Muramic acid \\
\hline Ile & Isoleucine & & \\
\hline Phe & Phenylalanine & & \\
\hline Leu & Leucine & & \\
\hline GABA & $\gamma$-Aminobutyric acid & & \\
\hline
\end{tabular}

Table 2. Glossary of abbreviations of sub-classes and individual amino acids and carbohydrates. 
DAA
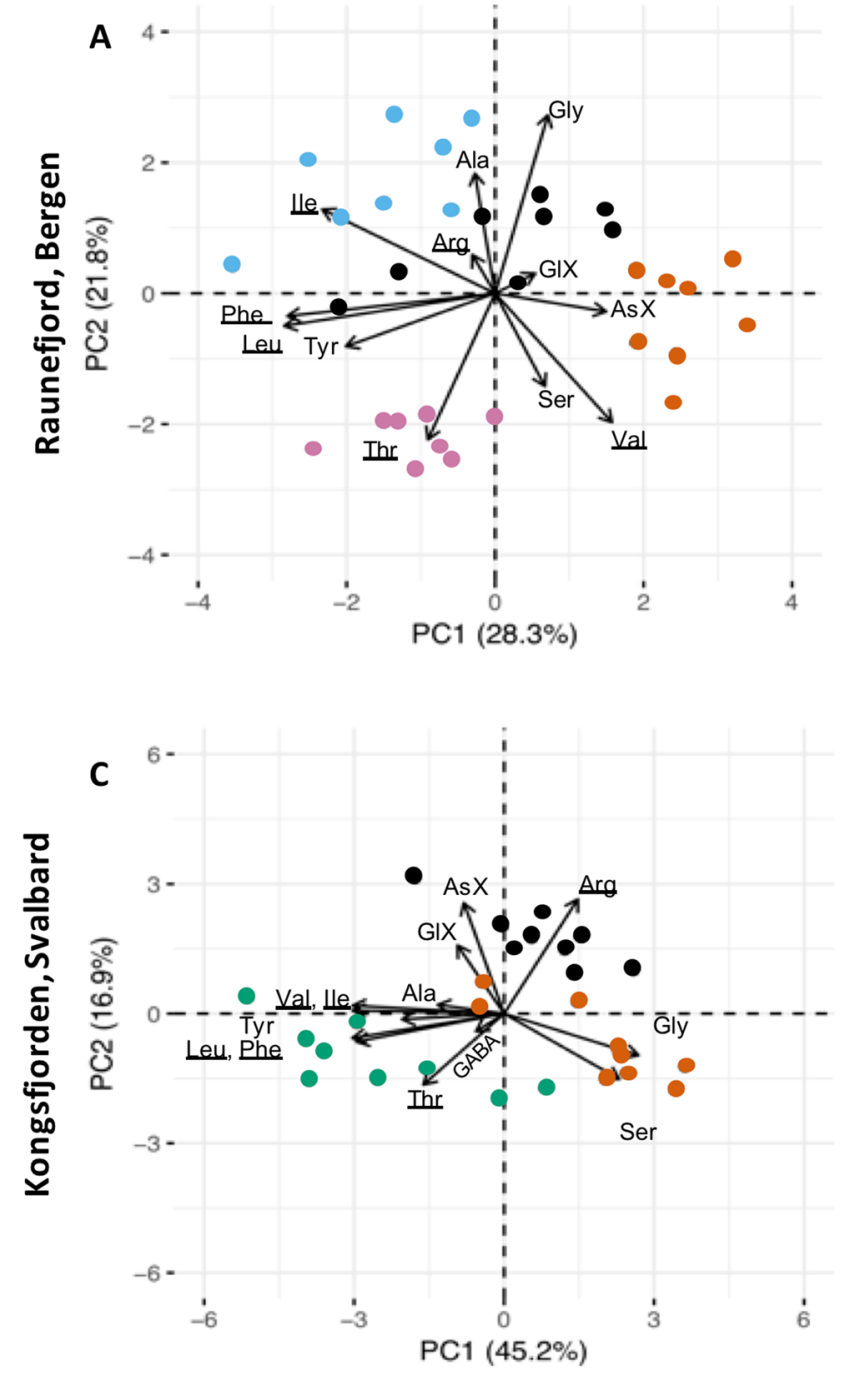


Bloom 1 (Bergen, Svalbard)

Post-Bloom 1 (Bergen)

Bloom 2 (Bergen, Svalbard)

Post-Bloom 2 (Bergen)

Bloom 3 (Svalbard)

Figure 4. PCA biplot of relative contribution of individual AA to total DAA (A) and PAA (B) concentration in Raunefjord/Bergen and total DAA (C) and PAA (D) in Kongsfjorden/Svalbard. The AA GABA was excluded from (A,B) and Gly from (D) (see "Material and methods" section for details). Refer to Table 2 for acronyms. Symbols color represents bloom stage. AA essential to higher trophic levels are underlined.

addition, during Bloom 2 and Post-Bloom 2, data points cluster together and show enrichment in Ala, and the essential AA Ile, Leu, Phe and Val.

Changes in $\mathrm{CHO}$ pools. Changes in the $\mathrm{CHO}$ pools were much less pronounced compared to AA and were restricted to a few individual compounds (Fig. 5). For example, in Raunefjord/Bergen only Glc showed significant positive correlation with decreasing $\mathrm{pH}$ during Bloom 1 and only Fuc, Gal and GlcN showed significant correlations with decreasing $\mathrm{pH}$ during Post-Bloom 1. Similarly, for Kongsfjorden/Svalbard only two CHO showed significant correlations within the DCHO during the entire experiments, namely, GlcA during Bloom 2 and Fuc during Bloom 3. Furthermore, significantly correlations for TCHO did also not show a clear pattern.

However, considering relative changes (mol\%) in CHO composition using PCA showed clear differences between (post-) bloom phases (Fig. 6). The first two components of these PCAs explained 45-64\% of the variation (Fig. 6). In Raunefjord/Bergen, both DCHO and TCHO, had higher relative contributions of Fuc, Man/ 

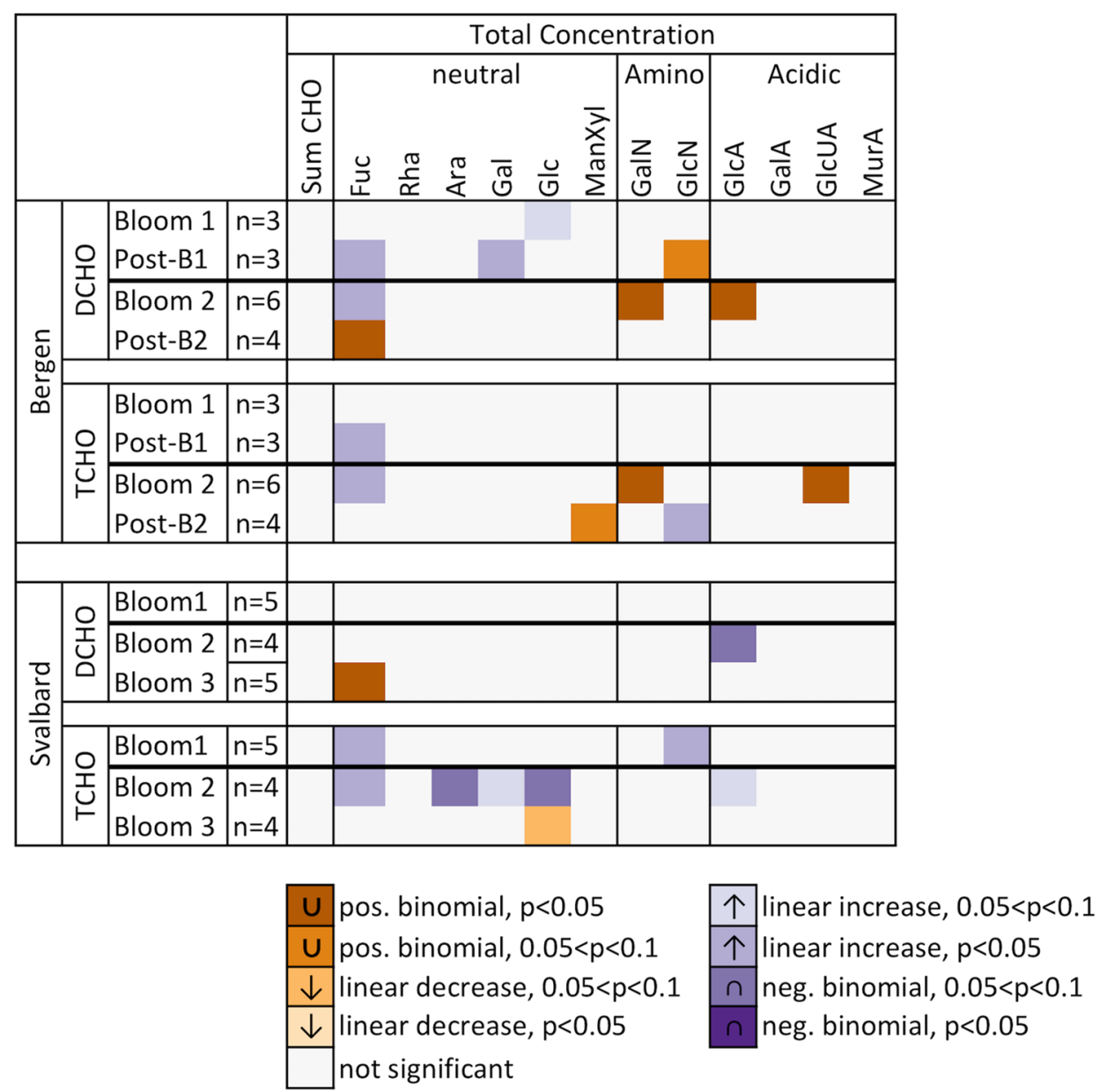

nuts add

Figure 5. Heat-map shows bloom phase-averaged response in mean deviation of concentrations of individual dissolved and total carbohydrates (DCHO, TCHO) with decreasing $\mathrm{pH}$. Refer to Table 2 for acronyms.

Xyl, GlcUA and MurA before nutrient addition. During Post-Bloom 2, the mesocosms formed a defined group that was enriched especially in neutral TCHO Rha and Gal as well as GalA (Fig. 6A,B).

In Kongsfjorden/Svalbard the DCHO pool was enriched in GalA, GalN, GlcA and Glc before nutrient addition, indicating that gel-like particles in the form of TEP may have been present in detectable forms (Fig. 6C). The TCHO pool in Kongsfjorden/Svalbard showed three distinct clusters. MurA was relatively enriched before nutrient additions, while after nutrient addition Gal, Fuc, Man/Xyl and GlcN showed enrichment during Bloom 2 and Rha, Ara, GalA, GlcA, GalN and GlcUA showed relative enrichment during Bloom 3 (Fig. 6D).

\section{Discussion}

Ocean acidification triggers increased primary production and DOC release in phytoplankton, as well as bacterial growth and respiration ${ }^{3,29-31}$. Investigations on semi-labile compounds such as AA and CHO however are currently scarce. During two mesocosm campaigns we determined the responses of AA and CHO quantity and quality (composition of individual compounds) as a response to $\mathrm{CO}_{2}$ addition. The quantity of AA and $\mathrm{CHO}$ is controlled by biomass production and their subsequent release into the DOC pool ${ }^{32,33}$. Increased rates of primary production and DOC release have previously been described for the Kongsfjord/Svalbard ${ }^{3}$ and is reflected in this study by increased contributions of DAA to DOC and DON during Bloom 2 in the Kongsfjorden/Svalbard experiment (Fig. S2). There were no significant differences in the contributions of DCHO and DAA to the total pool of DOC and the contributions of DAA to total DON for the majority of bloom phases. However, a more detailed look on the level of individual compounds revealed complex changes within the AA and CHO pools with some individual DAA seeming to be most affected by $\mathrm{pH}$ changes.

Overall, the total concentrations of DAA and DCHO measured in our study are within the range of other studies done in Arctic Seas ${ }^{7,34,35}$. $\mathrm{CO}_{2}$ dependent changes in AA and $\mathrm{CHO}$ seemed to be decoupled, lacking synchronized changes between the AA and $\mathrm{CHO}$ fractions. When AA concentrations are affected (depending on bloom-phase and fraction) most or even all individual AA were either increasing or decreasing. On the other hand, response in $\mathrm{CHO}$ was limited to a few individual compounds only. All investigated AA are involved in protein synthesis (except GABA), hence need to be produced in relative proportions. Therefore, AA concentrations 
DCHO
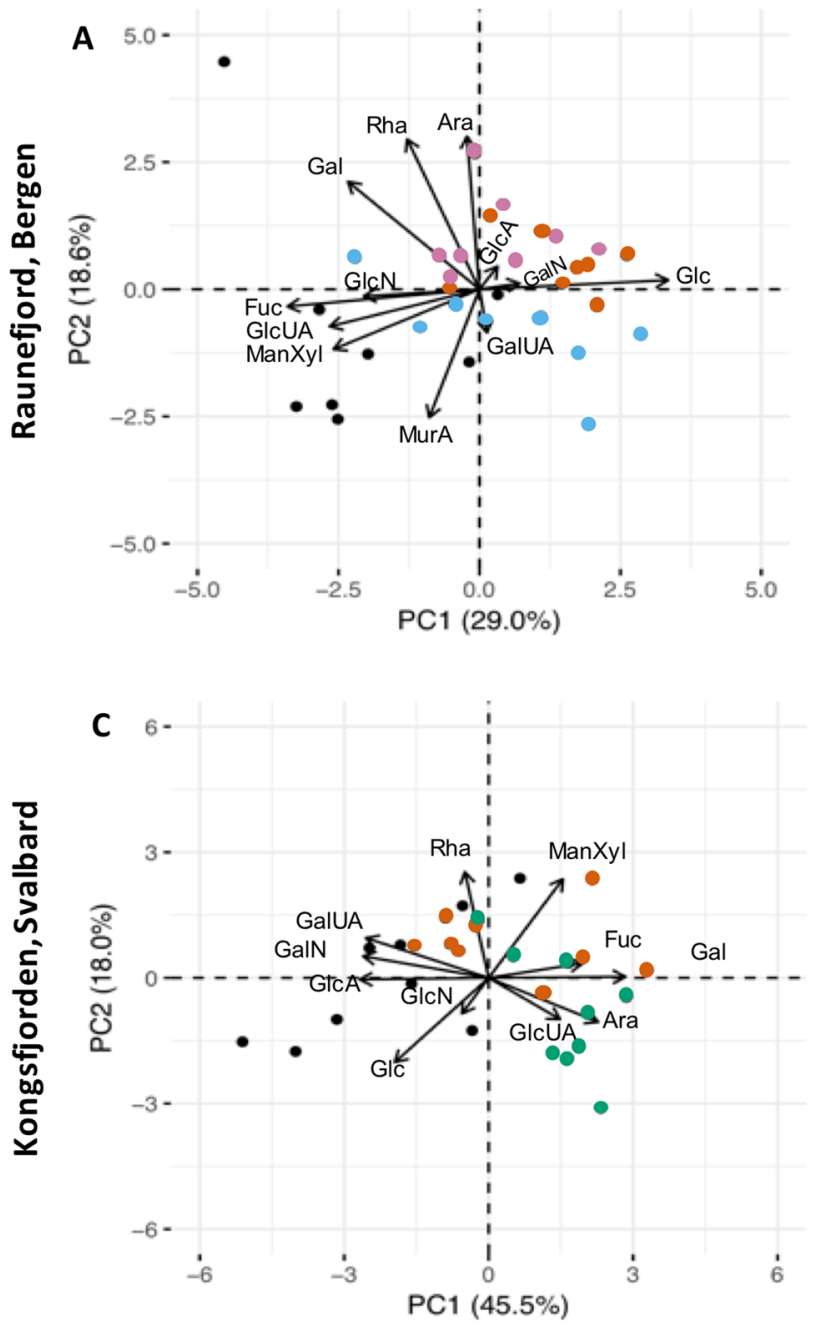

TCHO
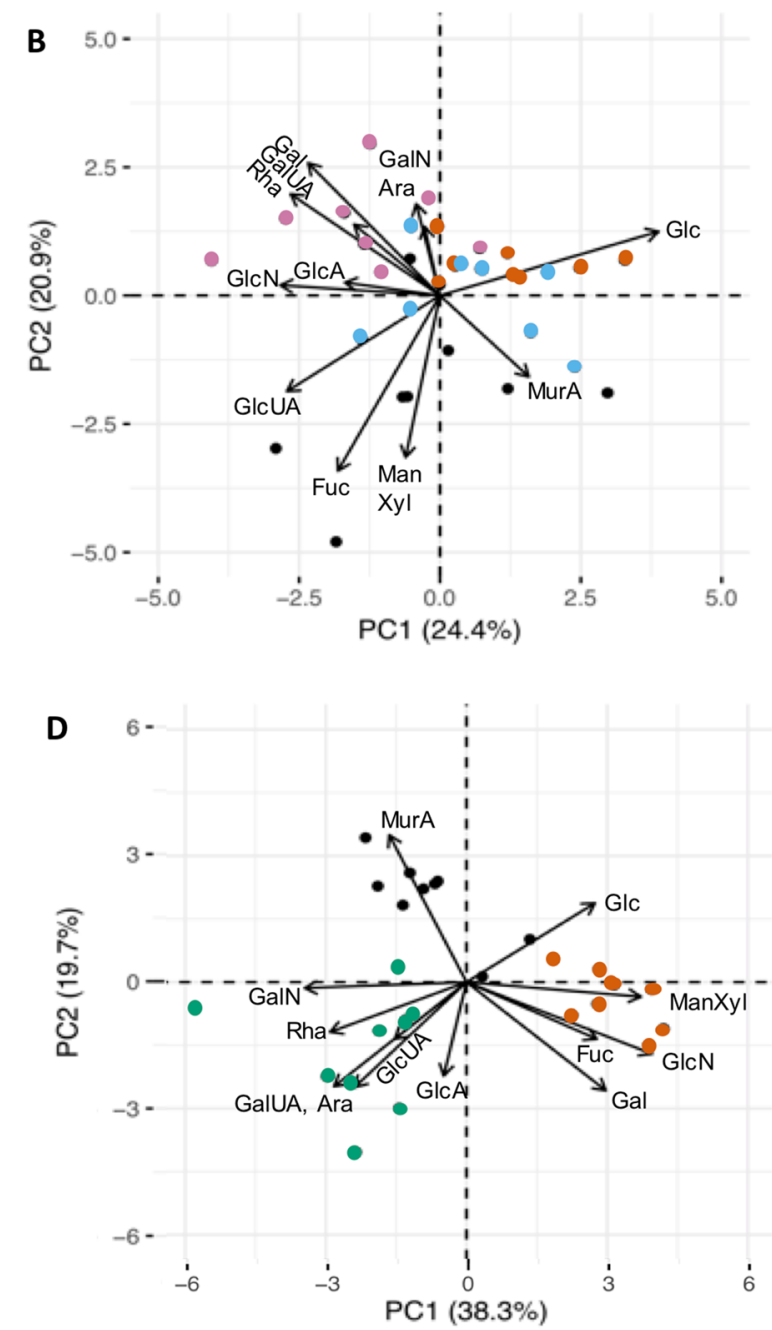



Figure 6. PCA biplot of relative contribution of individual $\mathrm{CHO}$ to total $\mathrm{DCHO}(\mathbf{A})$ and $\mathrm{TCHO}(\mathbf{B})$ concentration in Raunefjord/Bergen and total DCHO (C) and TCHO (D) in Kongsfjorden/Svalbard Experiment. Refer to Table 2 for acronyms. Symbols color represents bloom stage.

and composition in phytoplankton occur within a rather narrow margin across phytoplankton groups ${ }^{36}$. On the contrary, the composition of individual $\mathrm{CHO}$ to the total $\mathrm{CHO}$ pool varies greatly between different groups of phytoplankton ${ }^{37}$.

Another factor affecting relative changes in AA and $\mathrm{CHO}$ composition is nutrient availability. In our study, changes in \%mol occurred between bloom-phases especially in AA (Figs. 4,6). These qualitative changes can be linked to nutrient availability or changes in community composition ${ }^{32,38}$. For example, $\mathrm{N}$-availability affects the synthesis of EAA such as Phe, Ile, Leu and Val, because they require longer synthesis steps than NEAA. These additional synthesis steps in return require additional enzymes, proteins themselves, and down-regulation of certain amino acids during $\mathrm{N}$ scarcity limits $\mathrm{N}$ requirement of cells ${ }^{38}$. Usually, EAA cluster in PCA plots (Fig. 4, underlined compounds) and their contribution increases after nutrient addition. Furthermore, an increased contribution of GlX often indicates exponential bacterial growth ${ }^{39}$ and different bacterial communities can take up individual DAA preferentially ${ }^{40}$. CHO composition differs between phytoplankton groups, e.g. released DOC from the diatom Skeletonema costatum shows high contributions of Fuc, while haptophytes release larger relative amounts of Gal, Xyl and $\mathrm{Ara}^{41}$. MurA is uniquely found in bacterial cell walls and can be used to identify increased contributions of bacteria ${ }^{42}$, while nutrient limitation increases the synthesis of storage $\mathrm{CHO}$ such as 
glycan which is rich in $\mathrm{Glc}^{43}$. Overall, the dynamic changes in AA and $\mathrm{CHO}$ in organic matter are complex and emerging patterns seem to depend e.g. on site, nutrient availability, phytoplankton community structure, bacterial activity and likely additional factors.

$\mathrm{pCO}_{2} / \mathrm{pH}$ dependent trends in AA dynamics seemed much clearer in the Bergen campaign, with similar trends observed in the Svalbard campaign for a more limited set of AA. A direct effect of $\mathrm{CO}_{2}$ additions during the first bloom-phase was the decrease in DAA concentrations with decreasing $\mathrm{pH}$. Nutrient additions seem to have no direct effect on DAA during the second bloom. In Bergen, clear post-bloom phases existed and illustrated a reversed trend compared to the bloom phases. There DAA concentrations increased with decreasing $\mathrm{pH}$ demonstrating the release of labile DOM when bloom biomass was decaying. One could argue that it is imperative to distinguish between bloom and post-bloom phases to detect the described patterns, which should be considered in future studies, otherwise the opposite patterns may cancel each other out.

The two mesocosm campaigns were comparable in experimental design, length of study and the parameters sampled. However, the Raunefjord/Bergen campaign covered a much larger range of $\mathrm{pH} / \mathrm{pCO} \mathrm{CO}_{2}$ treatments, including three mesocosms that were beyond the $\mathrm{pH}$ predicted for $2100^{28}$. Deppeler et al. ${ }^{4}$ found that under high $p \mathrm{CO}_{2}$ (between 953 and $1140 \mu \mathrm{atm}$ ) the photosynthetic health of phytoplankton cells was negatively affected resulting in lower gross primary production. Lower primary production rates would subsequently result in a diminished DOC and DAA release. To investigate if such as tipping point was also present in the Raunefjorden/ Bergen mesocosms we applied a binomial fit to the data. We found that Bergen DAA concentrations displayed such as tipping point at a pH between 7.72 and $7.60\left(p \mathrm{CO}_{2} 890-1165 \mu \mathrm{atm}\right)$. At this threshold the phytoplankton tolerance to Ocean Acidification seems to have reached a point at which DAA release was not further increased with lower $\mathrm{pH}$ but reversed instead. Including the very high $p \mathrm{CO}_{2}$ mesocosms in Bergen confirms this tipping point at a similar $\mathrm{pH} / \mathrm{pCO}_{2}$ range. This needs to be taken into consideration when planning future studies and evaluating data trends. Additionally, the species composition of the phytoplankton community can further affect results and is needs to be considered. Some species (even within the same genus, e.g. Navicula) are better adapted to lower $\mathrm{pH}$ because they experience natural fluctuations over the annual cycle ${ }^{44,45}$. Fluctuations are especially large in polar waters where $\mathrm{CO}_{2}$ builds up under the sea ice in winter which is linked to respiratory processes due to a lack of light supporting primary production. In spring a rapid decrease in $\mathrm{CO}_{2}$ is linked to the spring bloom, and can cause an annual variation in $\mathrm{pH}$ of 0.8 units $^{45}$.

The two studies presented here differed in their initial phytoplankton community composition hence the two communities might have had different adaptation potentials to fluctuating $\mathrm{pH}$. The Bergen community was dominated by diatoms, with some chlorophytes, cryptophytes and haptophytes, reflecting composition more common during the spring bloom ${ }^{28}$. On the other hand, the community in Svalbard was typical for post-spring bloom conditions and included haptophytes, prasinophytes and only minor contributions of diatoms. Here, dinoflagellates also became significant contributors during Bloom 2 and Bloom $3^{27}$.

The increase of labile DOC in form of DAA and possibly other bioavailable molecules also fueled growth of the microbial communities in our study. This was visible in the increased concentrations of PAA, especially during the post-bloom phases in the Raunefjord/Bergen campaign. Assuming that PAA represents heterotrophic and autotrophic microorganisms our findings are in line with results from previous publications. Endres et al. ${ }^{25}$ detected an 11-21\% increase in bacterial biomass in high $p \mathrm{CO}_{2}$ mesocosms during Post-Bloom 1 and a $28 \%$ increase during Post-Bloom 2. Interestingly, the response in PAA is linear and does not show a $\mathrm{pH}$ threshold where the relationship reverses. This may be due to a better $\mathrm{pH}$ tolerance of extracellular enzymes used by heterotrophs, which show a higher efficiency under low $\mathrm{pH}$ conditions ${ }^{25,46}$. The lack of a clear signal in PAA in the Kongsfjorden/Svalbard campaign could be explained by the absence of increased bacterial biomass under elevated $p \mathrm{CO}_{2}{ }^{47}$. During this campaign bacterial numbers actually decreased in high $p \mathrm{CO}_{2}$ mesocosms and it was hypothesized that increased abundance of viruses led to higher levels of viral lysis resulting in a top-down control of bacterial biomass ${ }^{47}$, which however did not cause shifts in the bacterial community composition ${ }^{48}$.

Furthermore, gel-like particles may also play a role in fueling heterotrophic communities. TEP formation increased by $5-10 \%$ in high $p \mathrm{CO}_{2}$ mesocosms in Bergen under nutrient limited conditions ${ }^{25}$. While increased bacterial abundance is reflected by increased relative concentrations of PAA, increased TEP contribution is not easily detected within our TCHO. Increased contributions of TEP to TCHO would be indicated by elevated contributions of acidic sugars ${ }^{21}$. We would have expected elevated concentrations or increased relative contributions of e.g. GlcA, GalA or GlcUA to reflect a build-up in TEP. During the Raunefjord/Bergen campaign TEP peaked at the end of bloom phase 1 and $2^{25}$, however no detectable changes occurred in the CHO composition (Fig. 6). On the other hand, these TEP-related CHO showed enrichment during Bloom 3 in Kongsfjorden, indicating that TEP may have been increasingly abundant there. It therefore seems to be important to determine changes in TEP concentrations separately and not infer TEP abundance from changes in biomolecule composition.

The increase in DOC released from primary production under future ocean conditions has been described before $^{3,30}$. Concurrently, this seems to also result in an increase in semi-labile compounds especially DAA and some DCHO. Contributions of \% DAA to DOC were significant for some mesocosms in Kongsfjorden/Svalbard and for 7 out of 8 in Raunefjord/Bergen $(\mathrm{p}<0.05)$. Here, changes were also correlated with $p \mathrm{CO}_{2}$ during two bloom phases (Bloom 1 in Raunefjord/Bergen and Bloom 2 in Kongsfjorden/Svalbard, Fig. S2). On the contrary, contributions of \% DCHO to DOC only showed significant increased contributions in two mesocosms in Kongsfjorden/Svalbard $\left(p \mathrm{CO}_{2}=890,3045 \mu \mathrm{atm}, \mathrm{p}<0.05\right)$ and control mechanisms should be investigated further (Fig. S2).

Potential consequences of increased contributions of semi-labile DOC with increasing $p \mathrm{CO}_{2}$ would stimulate the microbial carbon pump. Freshly produced DOC is quickly taken up, respired and reworked by bacteria leaving behind degraded and less bioavailable DOC that eventually will become part of the refractory organic matter pool ${ }^{49,50}$. Remineralization processes will enhance bacterial production, respiration and have a negative 
feedback on $p \mathrm{CO}_{2}{ }^{30,31}$. The refractory carbon left behind will in turn be transported to greater depths and stored in deeper ocean waters thereby sequestering atmospheric $\mathrm{CO}_{2}{ }^{51}$.

Under future ocean conditions, enhanced uptake of organic compounds and bacterial activity may also lead to increased competition for inorganic nutrients between autotrophs and heterotrophs with bacteria winning since heterotrophic bacteria are generally more successful in acquiring inorganic nutrients ${ }^{52}$. However, phytoplankton communities in low $\mathrm{pH}$ mesocosms shifted towards smaller sized phytoplankton ${ }^{28,47}$. Smaller species seem to be more tolerable to lower $\mathrm{pH}$ compared to larger species and benefit from a larger surface to volume ratios to effectively compete for inorganic nutrients ${ }^{53}$. High bacterial biomass may also be an advantage for mixotrophic protists, phytoplankton capable of bacterivory. In Kongsfjorden/Svalbard, numbers of dinoflagellates (a group containing mixotrophic species) positively correlated with elevated $p \mathrm{CO}_{2}$ during Bloom 2 and Bloom $3^{27,54}$ hinting that they might use bacteria as a food source. However, their top-down impact on bacterial biomass in high $p \mathrm{CO}_{2}$ mesocosms can only be speculated about. Additionally, a recent study by Anderson et al. ${ }^{55}$ showed that $40 \%$ and more of smaller phytoplankton $(<20 \mu \mathrm{m})$ also exhibited signs of bacteriovory, suggesting that this lifestyle might become more prominent under elevated $p \mathrm{CO}_{2}$. Hence more data is needed to determine if autotrophic biomass production and activity will be reduced in the future ocean as postulated by Thingstad et al. ${ }^{56}$.

Phytoplankton produces many AA and fatty acids that are essential to higher trophic levels. An increase in essential PAA contribution at the end of both campaigns (Fig. 4B,D) hint that the microbial biomass contained sufficient essential AA to be transported up the food chain to higher trophic levels. Essential FA content on the other hand diminishes under elevated $\mathrm{pCO}_{2}{ }^{57}$ and a smaller sized community decreases energy transfer efficiencies because more trophic intermediates are required to reach the highest trophic levels, reducing trophic transfer efficiency. This means that the verdict is still out on the extent of effects on food web interactions.

\section{Material and methods}

Experimental set-up of mesocosms and bloom development. Two mesocosm studies were conducted to investigate the effect of $p \mathrm{CO}_{2}$ changes on Arctic and Sub-Arctic marine ecosystems. In total, nine 25 m-long, free-floating Kiel Off-Shore Mesocosms for Future Ocean Simulations (KOSMOS) with flexible thermoplastic Polyurethane bags $\left(\sim 50 \mathrm{~m}^{3}\right)$ were deployed in Kongsfjorden, Svalbard $\left(78.93^{\circ} \mathrm{N}, 11.89^{\circ} \mathrm{E}\right)$, in June-July 2010 and again in the Raunefjord near Bergen, Norway in April-June $2011\left(60.31^{\circ} \mathrm{N}, 5.16^{\circ} \mathrm{E}\right)$. In both campaigns, a $\mathrm{CO}_{2}$ gradient was applied with eight different $\mathrm{CO}_{2}$ levels, only duplicating ambient $\mathrm{CO}_{2}$ conditions (control treatment without $\mathrm{CO}_{2}$ addition) ${ }^{28,58}$. Initial $p \mathrm{CO}_{2}$ levels were achieved by adding $\mathrm{CO}_{2}$ enriched seawater at different quantities. Samples for all parameters were taken with a depth-integrating water sampler (Hydrobios Kiel, Germany) for 1-15 m and 1-23 m, respectively. Daily vertical profiles were taken with a handoperated CTD. Nutrient additions were performed to simulate upwelling of nutrient rich water and to stimulate a second phytoplankton bloom.

Kongsfjorden/Svalbard. Mesocosms were filled on 28 May 2010 with nutrient-poor, post-bloom fjord water $\left(\sim 50 \mathrm{~m}^{3}\right.$ each). A $3 \mathrm{~mm}$ mesh size net was used to exclude large organisms. The bags were closed on 31 May 2010, defined as time $\mathrm{t}_{-7}$ and time steps $(\mathrm{t})$ continued per day. The $\mathrm{CO}_{2}$ manipulation was done in steps over 5 days, from $t_{-1}$ to $t_{4}$, by adding calculated amounts of $\mathrm{CO}_{2}$ enriched seawater to 7 of the 9 mesocosm. Two did not receive additions and served as controls. Main $\mathrm{CO}_{2}$ additions were done from $t_{-1}$ to $t_{2}$ and a final adjustment was done on $\mathrm{t}_{4}$. Control mesocosms had initial $p \mathrm{CO}_{2}$ levels of $185 / \mathrm{pH} \sim 8.32$. The other mesocosms had initial $\mathrm{pCO}_{2}$ levels between 270 and $1420 \mu \mathrm{atm} / \mathrm{pH}$ 8.18-7.51 (detailed $\mathrm{pH}$ dynamics are provided by Schulz et al. ${ }^{27}$ ). Carbon system measurements and calculations were published in Bellerby et al. ${ }^{59}$. In short, total inorganic carbon and total alkalinity were measured. Partial pressure of $\mathrm{CO}_{2}\left(p \mathrm{CO}_{2}\right)$ and $\mathrm{pH}$ on the total hydrogen scale were calculated using salinity, temperature, dissolved nutrients and applying them with the CO2SYS program. Detailed development of $\mathrm{pH}$ is shown in Fig. S3.

Initial nutrient concentrations in the fjord water were $<0.1 \mu \mathrm{M}$ nitrate, $0.09 \mu \mathrm{M}$ phosphate, $0.2 \mu \mathrm{M}$ silicate and $0.7 \mu \mathrm{M}$ ammonium ${ }^{27}$. Additional inorganic nutrients were added at $\mathrm{t}_{13}(5 \mu \mathrm{M}$ nitrate, $0.32 \mu \mathrm{M}$ phosphate, and $2.5 \mu \mathrm{M}$ silicate) and the experiment was terminated at $t_{30}$. The experimental period was divided into three phases by previous authors ${ }^{27}$ based on the applied perturbations and $\mathrm{Chl} a$ dynamics covering the onset and demise of phytoplankton blooms. "Bloom 1 " occurred before nutrient addition $\left(\mathrm{t}_{4-13}\right)$, "Bloom 2 " occurred after nutrient addition until the 2 nd $\mathrm{Chl} a$ minimum $\left(\mathrm{t}_{14-21}\right)$ and "Bloom 3 " was from the 2 nd Chl $a$ minimum until the end of the experiment $\left(\mathrm{t}_{22-29}\right)^{27}$. No clear post-bloom phases (longer period of low Chl $a$ concentrations) were observed during this campaign.

Raunefjord/Bergen. Mesocosms were filled and closed on 30 April 2011, defined as time $\mathrm{t}_{-8}$. Seven mesocosms were adjusted over 5 days to $\mathrm{pCO}_{2}$ target levels $\sim 400$ to $3000 \mu \mathrm{atm} / \mathrm{pH} 8.13-7.20$ by stepwise addition of $\mathrm{CO}_{2}$ saturated seawater (detailed information are given in Schulz et al. $\left.{ }^{28}\right)$. The control mesocosm M2 $(300 \mu \mathrm{atm} / \mathrm{pH}$ 8.14) was omitted from statistical analysis because a hole was discovered during the first week of the experiment which could not be mended and salinity changes confirmed that several cubic meter of ford water were exchanged. Carbon system measurements and calculations were published in Schulz et al. ${ }^{28}$. In short, $\mathrm{pH}$ was measured spectrophotometrically and presented on the total hydrogen scale. Dissolved inorganic carbon (DIC) was measured coulometrically and $\mathrm{pH}$ and $\mathrm{DIC}$ were used at in-situ temperature and salinitiy to calculate $p \mathrm{CO}_{2}$ and other carbonate system speciations. Detailed development of DIC and pH are shown in Fig. S4.

Initial concentrations of inorganic nutrients were higher than in the Svalbard campaign displaying $1.5 \mu \mathrm{M}$ nitrate, $0.2 \mu \mathrm{M}$ phosphate, $1.2 \mu \mathrm{M}$ silicate and $0.45 \mu \mathrm{M}$ ammonium ${ }^{28}$. The total added concentrations of nutrients at time $\mathrm{t}_{14}$ were $5 \mu \mathrm{M}$ nitrate and $0.16 \mu \mathrm{M}$ phosphate. No silicate was added to facilitate the growth of Emiliania huxleyi. The experiment was terminated at $t_{35}$. Again, the experimental period was divided into four phases 
in previous publications ${ }^{27,47}$ based on the applied perturbations and Chl a dynamics. During "Bloom1" $\left(\mathrm{t}_{3-8}\right)$ inorganic nutrients were rapidly taken up and lead to a first phytoplankton bloom. During the following "PostBloom1" $\left(t_{9-14}\right)$, there was little change in autotrophic biomass at low nitrate and phosphate availability. "Bloom 2" was after nutrient addition which initiated a second phytoplankton bloom $\left(\mathrm{t}_{15-25}\right)$ and the "Post-Bloom2" $\left(\mathrm{t}_{26-34}\right)$ showed again little change in autotrophic biomass, probably due to low phosphate availability.

We use the applied classification of bloom and post bloom phases to average our data.

A detailed description of the experimental setup, its deployment, technical features and the sampling methods are described by Schulz et al..$^{27,28}$ and references therein.

Chlorophyll $\boldsymbol{a}$ and dissolved organic carbon and nitrogen. Chlorophyll $a(\mathrm{Chl} a)$ for the Raunefjord/ Bergen experiment, as well as Chl $a$, dissolved organic carbon (DOC) and nitrogen (DON) data for the Kongsfjorden/Svalbard experiment have been published elsewhere ${ }^{3,27,28,46}$ and were either retrieved from Pangaea ${ }^{60}$ or provided by the authors. DOC and DON samples for Raunefjord/Bergen experiment were collected and analyzed as described by Engel et al. ${ }^{3}$, and references therein. In short, $20 \mathrm{ml}$ of sample was filtered through combusted GF/F filters and collected in combusted glass ampules. Samples were acidified with $100 \mu \mathrm{L}$ of $85 \%$ phosphoric acid, heat sealed and stored at $4^{\circ} \mathrm{C}$ in the dark until analysis. DOC samples were analyzed using the hightemperature combustion method (TOC-VCSH, Shimadzu). Total Dissolved Nitrogen (TDN) was determined with the TNM-1detector on the Shimadzu analyzer, which combusts nitrogen to $\mathrm{NO}_{\mathrm{x}}$. $\mathrm{NO}_{\mathrm{x}}$, chemiluminesces when mixed with ozone and is then detected using a photomultiplier ${ }^{61}$. DON concentrations were calculated by subtracting values of dissolved inorganic nitrogen concentrations (nitrate, nitrite, and ammonium). Sampling frequency was daily.

Total and dissolved AA composition. TAA and DAA were determined separately. For TAA, $5 \mathrm{~mL}$ of sample were filled into pre-combusted glass vials $\left(8 \mathrm{~h}, 500{ }^{\circ} \mathrm{C}\right)$ and stored at $-20^{\circ} \mathrm{C}$ until analysis. Samples for DAA were additionally filtered through $0.45 \mu \mathrm{m}$ Acrodisc syringe filters before storage. Analysis was performed according to Lindroth and Mopper ${ }^{62}$ and Dittmar et al. ${ }^{63}$, with some modifications. In short, $1 \mathrm{~mL}$ of sample and $1 \mathrm{~mL}$ of $30 \%$ hydrochloric acid (Merck, suprapure) were hydrolyzed in sealed ampoules at $100{ }^{\circ} \mathrm{C}$ for $20 \mathrm{~h}$. The hydrolysate was dried in a microwave at $60^{\circ} \mathrm{C}$ under a nitrogen atmosphere and was washed twice with $0.5 \mathrm{~mL}$ of ultrapure water to remove any remaining acid. The final sample was re-dissolved in $1 \mathrm{~mL}$ ultrapure water for analysis. Analysis was performed on a 1260 HPLC system (Agilent) equipped with a C18 column (Phenomenex Kinetex, $2.6 \mu \mathrm{m}, 150 \times 4.6 \mathrm{~mm}$ ) that can separate thirteen different AA after in-line derivatization with o-phtaldialdehyde and mercaptoethanol. Solvent A was 5\% Acetonitrile (LiChrosolv, Merck, HPLC gradient grade) in Sodiumdihydrogenphospate (Merck, suprapur) Buffer ( $\mathrm{pH} 7.0$ ) and Solvent B was Acetonitrile, from 100\% solvent A to 78\% solvent A in $50 \mathrm{~min}$. The detection limit for individual AA was $2 \mathrm{nmol} \mathrm{monomer/L}$. The precision was $<5 \%$, estimated as the standard deviation of replicate measurements divided by the mean. The following standards were used: asparagine + aspartic acid (AsX), glutamine + glutamic acid (GIX), serine (Ser), glycine (Gly), threonine (Thr), arginine (Arg), alanine (Ala), tyrosine (Tyr), valine (Val), isoleucine (Ile), phenylalanine (Phe), and leucine (Leu). $\gamma$-Aminobutyric acid (GABA) concentrations were below the detection limit in DAAs of Kongsfjorden/Svalbard mesocosms.

PAA concentrations were calculated: PAA $=$ TAA - DAA. For a few individual AA in selected samples this resulted in negative values (DAA concentrations $\geq$ TAA concentrations) and values were omitted from the analysis. Throughout the Kongsfjorden/Svalbard dataset Gly in DAA was higher in concentrations than in TAA giving negative results and therefore Gly was omitted from the PAA fraction. This was probably due to a problem with the Gly standard during TAA analysis. Sampling frequency was every other day to keep sample number manageable during analysis.

Total and dissolved CHO composition. TCHO and $\mathrm{DCHO}>1 \mathrm{kDa}$ were determined separately. Therefore, $20 \mathrm{~mL}$ were filled into pre-combusted glass vials $\left(8 \mathrm{~h}, 500^{\circ} \mathrm{C}\right)$ and kept frozen at $-20^{\circ} \mathrm{C}$ until analysis. Samples for DCHO were additionally filtered through $0.45 \mu \mathrm{m}$ Acrodisc syringe filters before storage. The analysis was conducted according to Engel and Händel ${ }^{64}$. First, samples were desalinated by membrane dialysis $(1 \mathrm{kDa}$ MWCO, Spectra Por) for $5 \mathrm{~h}$ at $1{ }^{\circ} \mathrm{C}$, hydrolyzed for $20 \mathrm{~h}$ at $100^{\circ} \mathrm{C}$ with $0.4 \mathrm{M} \mathrm{HCl}$, final concentration, and then neutralized through acid evaporation under vacuum and nitrogen atmosphere $\left(1 \mathrm{~h}, 60^{\circ} \mathrm{C}\right)$. Samples were analyzed using high performance anion exchange chromatography coupled with pulsed amperometric detection (HPAEC-PAD) on a Dionex ICS 3000. The system was calibrated with a mixed sugar standard solution including the neutral sugars: fucose (Fuc), rhamnose (Rha), arabinose (Ara), galactose (Gal), xylose/mannose (Xyl/ $\mathrm{Man})$ and glucose $(\mathrm{Glc})$, the amino sugars: galactosamine $(\mathrm{GalN})$, glucosamine $(\mathrm{GlcN})$, and the acidic sugars: galacturonic acid (GalUA), gluconic acid (GluA), glucuronic acid (GlcUA) and muramic acid (MurA). Particulate $\mathrm{CHO}$ concentrations were not determined, because DCHO and TCHO concentrations were very similar or equal, which resulted in negative particulate $\mathrm{CHO}$ concentrations for several of the data points throughout the dataset. When differences between DCHO and TCHO are small, these negative values can occur for two reasons. Firstly, during dialysis some TCHO can escape through the membrane $(>1 \mathrm{kDa})$ and affect final concentrations. Secondly, we run DCHO and TCHO batches separately (instead of DCHO sample followed by TCHO of same sampling point). Maintenance of the HPAEC-PAD system and exchange of analytical columns could induce minor differences in the calculated final concentrations. Sampling frequency was every other day to keep sample number manageable during analysis.

Data analysis and statistics. To identify $p \mathrm{CO}_{2}$ dependent trends in AA and CHO concentrations we applied the method described by Endres et $\mathrm{al}^{25}$. In short, the daily deviation $\left(\mathrm{AD}_{i}\right)$ of each mesocosm was 
calculated by subtracting observed concentration $\left(X_{i}\right)$ from the average concentration of all mesocosms $(\bar{X})$ for each sampling day $\left(A D_{i}=X_{i}-X\right)$. These daily deviations were checked for normality by inspection of histograms and Q-Q diagrams. In order to get the mean deviations $(M D)$ of the entire bloom phase, all daily deviations per bloom and post-bloom phase were averaged, respectively, according to $\frac{1}{N} \sum_{i=1}^{N}\left(A D_{i}\right)$ with $N$ being the number of sampling days. Especially for the bloom phases this is important, as the bloom peaks were not reached at the same day across all mesocosms. The mean deviations were tested against initial $\mathrm{pH}$ of the different mesocosms by linear regression. If linear regression did not show significance levels $\mathrm{p} \leq 0.1$, a binomial regression was performed and significance was tested. This allows detection of trends that have a significant linear regression for a more limited $\mathrm{pH}$-range.

Principle component analysis (PCA) was performed to explore differences in individual AA and CHO composition between different Bloom/Post-Bloom phases. Data for the relative contribution (\%) of individual AA and $\mathrm{CHO}$ concentrations to sum of $\mathrm{AA}$ and $\mathrm{CHO}$ concentrations ( $\mathrm{nmol} \mathrm{L}$ ) was used. The package CRAN:factoMineR in the open source software R was used for the PCA analysis using a correlation matrix.

\section{Data availability}

Concentration data for DOC, DON, TAA; DAA; TCHO and DCHO are openly available through the Pangaea repository: https://doi.pangaea.de/10.1594/PANGAEA.920945 (Svalbard), https://doi.pangaea.de/10.1594/ PANGAEA.921093 (Bergen). All other relevant data are available from the corresponding author upon request.

Received: 12 November 2019; Accepted: 12 November 2020

Published online: 26 November 2020

\section{References}

1. Feely, R. A., Doney, S. C. \& Cooley, S. R. Ocean acidification: Present conditions and future changes in a high-CO world. Oceanography 22, 36-47 (2009).

2. IPCC. Summary for policymakers. in IPCC Special Report on the Ocean and Cryosphere in a Changing Climate (eds. H.-O. Pörtner, D.C. Roberts, V. Masson-Delmotte, P. Zhai, M. Tignor, E. Poloczanska, K. Mintenbeck, A. Alegría, M. Nicolai, A. Okem, J. Petz, N. M. W.). I. Press. https://www.ipcc.ch/srocc/cite-report/ (2019).

3. Engel, A. et al. $\mathrm{CO}_{2}$ increases ${ }^{14} \mathrm{C}$-primary production in an Arctic plankton community. Biogeosciences 10, 1291-1308 (2013).

4. Engel, A. et al. Effects of $\mathrm{CO}_{2}$ on particle size distribution and phytoplankton abundance during a mesocosm bloom experiment (PeECE II). Biogeosciences 5, 509-521 (2008).

5. Rost, B., Zondervan, I. \& Wolf-Gladrow, D. Sensitivity of phytoplankton to future changes in ocean carbonate chemistry: Current knowledge, contradictions and research directions. Mar. Ecol. Prog. Ser. 373, 227-237 (2008).

6. Benner, R. Chemical composition and reactivity. Biogeochem. Mar. Dissolved Org. matter 3, 56-90 (2002).

7. Meon, B. \& Kirchman, D. L. Dynamics and molecular composition of dissolved organic material during experimental phytoplankton blooms. Mar. Chem. 75, 185-199 (2001).

8. Carlson, C. A. Production and removal processes. Biogeochem. Mar. Dissolved Org. Matter 4, 91-151 (2002).

9. Del Giorgio, P. A. \& Duarte, C. M. Respiration in the open ocean. Nature 420, 379 (2002).

10. Suess, E. Particulate organic carbon flux in the oceans-Surface productivity and oxygen utilization. Nature 288, 260 (1980).

11. Martin, J. H., Knauer, G. A., Karl, D. M. \& Broenkow, W. W. VERTEX: Carbon cycling in the northeast Pacific. Deep Sea Res. Part A. Oceanogr. Res. Pap. 34, 267-285 (1987).

12. Grossart, H. P., Allgaier, M., Passow, U. \& Riebesell, U. Testing the effect of $\mathrm{CO}_{2}$ concentration on the dynamics of marine heterotrophic bacterioplankton. Limnol. Oceanogr. 51, 1-11 (2006).

13. Schulz, K. G. et al. Build-up and decline of organic matter during PeECE III. Biogeosciences 5, 707-718 (2008).

14. Maugendre, L. et al. No detectable effect of ocean acidification on plankton metabolism in the NW oligotrophic Mediterranean Sea: Results from two mesocosm studies. Estuar. Coast. Shelf Sci. 186, 89-99 (2017).

15. Paul, A. J. et al. Effect of elevated $\mathrm{CO}_{2}$ on organic matter pools and fluxes in a summer Baltic Sea plankton community. Biogeosciences 12, 6181-6203 (2015).

16. Yoshimura, T. et al. Impacts of elevated $\mathrm{CO}_{2}$ on organic carbon dynamics in nutrient depleted Okhotsk Sea surface waters. J. Exp. Mar. Bio. Ecol. 395, 191-198 (2010).

17. Claybrook, D. L. Nitrogen metabolism. In Internal Anatomy and Physiological Regulation. The Biology of Crustacea. CLAYBROOK (ed. Mantel, L. H.) 163-213 (Academic Press Inc, New York, 1983).

18. Burian, A., Grosse, J., Winder, M. \& Boschker, H. T. S. Nutrient deficiencies and the limits of physiological regulation in copepods. Funct. Ecol. 32(3), 626-647 (2018).

19. Piontek, J. et al. The utilization of polysaccharides by heterotrophic bacterioplankton in the Bay of Biscay (North Atlantic Ocean). J. Plankton Res. 33, 1719-1735 (2011).

20. Engel, A., Thoms, S., Riebesell, U., Rochelle-Newall, E. \& Zondervan, I. Polysaccharide aggregation as a potential sink of marine dissolved organic carbon. Nature 428, 929-932 (2004).

21. Alldredge, A. L., Passow, U. \& Logan, B. E. The abundance and significance of a class of large, transparent organic particles in the ocean. Deep Sea Res. Part I Oceanogr. Res. Pap. 40, 1131-1140 (1993).

22. Verdugo, P. et al. The oceanic gel phase: A bridge in the DOM-POM continuum. Mar. Chem. 92, 67-85 (2004).

23. Long, R. A. \& Azam, F. Abundant protein-containing particles in the sea. Aquat. Microb. Ecol. 10, 213-221 (1996).

24. Azam, F. \& Malfatti, F. Microbial structuring of marine ecosystems. Nat. Rev. Microbiol. 5, 782 (2007).

25. Endres, S., Galgani, L., Riebesell, U., Schulz, K. G. \& Engel, A. Stimulated bacterial growth under elevated $p \mathrm{CO}_{2}:$ results from an off-shore mesocosm study. PLoS One 9(6), e99228 (2014).

26. MacGilchrist, G. A. et al. Effect of enhanced $p \mathrm{CO}_{2}$ levels on the production of dissolved organic carbon and transparent exopolymer particles in short-term bioassay experiments. Biogeosciences 11, 3695-3706 (2014).

27. Schulz, K. G. et al. Temporal biomass dynamics of an Arctic plankton bloom in response to increasing levels of atmospheric carbon dioxide. Biogeosciences 10, 161-180 (2013).

28. Schulz, K. G. et al. Phytoplankton blooms at increasing levels of atmospheric carbon dioxide: Experimental evidence for negative effects on prymnesiophytes and positive on small picoeukaryotes. Front. Mar. Sci. 4, 64 (2017)

29. Riebesell, U. et al. Enhanced biological carbon consumption in a high $\mathrm{CO}_{2}$ ocean. Nature 450, 545-548 (2007).

30. Torstensson, A., Hedblom, M., Mattsdotter Björk, M., Chierici, M. \& Wulff, A. Long-term acclimation to elevated $\mathrm{pCO}_{2}$ alters carbon metabolism and reduces growth in the Antarctic diatom Nitzschia lecointei. Proc. Biol. Sci. 282(1815), 20151513 (2015).

31. James, A. K. et al. Elevated $\mathrm{pCO}_{2}$ enhances bacterioplankton removal of organic carbon. PLoS ONE 12, e0173145 (2017). 
32. Wu, Y. et al. Seasonal dynamics of particulate organic matter in the Changjiang Estuary and adjacent coastal waters illustrated by amino acid enantiomers. J. Mar. Syst. 154, 57-65 (2016).

33. Sarmento, H. et al. Phytoplankton species-specific release of dissolved free amino acids and their selective consumption by bacteria. Limnol. Oceanogr. 58, 1123-1135 (2013).

34. Ji, C.-X., Yang, G.-P., Chen, Y. \& Zhang, P.-Y. Distribution, degradation and bioavailability of dissolved organic matter in the East China Sea. Biogeochemistry 142, 189-207 (2019).

35. Shen, Y., Benner, R., Kaiser, K., Fichot, C. G. \& Whitledge, T. E. Pan-arctic distribution of bioavailable dissolved organic matter and linkages with productivity in ocean margins. Geophys. Res. Lett. 45, 1490-1498 (2018).

36. Finkel, Z. V. et al. Phylogenetic diversity in the macromolecular composition of microalgae. PLoS One 11(5), e0155977 (2016).

37. Brown, M. R. The amino-acid and sugar composition of 16 species of microalgae used in mariculture. J. Exp. Mar. Bio. Ecol. 145, 79-99 (1991).

38. Grosse, J., Brussaard, C. P. D. \& Boschker, H. T. S. Nutrient limitation driven dynamics of amino acids and fatty acids in coastal phytoplankton. Limnol. Oceanogr. https://doi.org/10.1002/lno.11040 (2018).

39. Kuznetsova, M. \& Lee, C. Dissolved free and combined amino acids in nearshore seawater, sea surface microlayers and foams: Influence of extracellular hydrolysis. Aquat. Sci. 64, 252-268 (2002).

40. Davis, J., Kaiser, K. \& Benner, R. Amino acid and amino sugar yields and compositions as indicators of dissolved organic matter diagenesis. Org. Geochem. 40, 343-352 (2009).

41. Biersmith, A. \& Benner, R. Carbohydrates in phytoplankton and freshly produced dissolved organic matter. Mar. Chem. 63, 131-144 (1998).

42. Ogawa, H., Amagai, Y., Koike, I., Kaiser, K. \& Benner, R. Production of refractory dissolved organic matter by bacteria. Science (80-). 292, 917 LP - 920 (2001)

43. Borsheim, K. Y. et al. Photosynthetic algal production, accumulation and release of phytoplankton storage carbohydrates and bacterial production in a gradient in daily nutrient supply. J. Plankton Res. 27, 743-755 (2005).

44. Deppeler, S. et al. Ocean acidification of a coastal Antarctic marine microbial community reveals a critical threshold for $\mathrm{CO}_{2}$ tolerance in phytoplankton productivity. Biogeosciences 15, 209-231 (2018).

45. Thoisen, C., Riisgaard, K., Lundholm, N. \& Nielsen, T. G. Effect of acidification on an Arctic phytoplankton community from Disko Bay. West Greenland. Mar. Ecol. Prog. Ser. 520, 21-34 (2015).

46. Piontek, J. et al. Response of bacterioplankton activity in an Arctic fjord system to elevated $p \mathrm{CO}_{2}$ : Results from a mesocosm perturbation study. Biogeosciences 10, 297-314 (2013).

47. Brussaard, C. P. D. et al. Arctic microbial community dynamics influenced by elevated $\mathrm{CO}_{2}$ levels. Biogeosciences 10, 719-731 (2013).

48. Roy, A.-S. et al. Ocean acidification shows negligible impacts on high-latitude bacterial community structure in coastal pelagic mesocosms. Biogeosciences 10, 555-566 (2013).

49. Benner, R. \& Kaiser, K. Abundance of amino sugars and peptidoglycan in marine particulate and dissolved organic matter. Limnol. Oceanogr. 48, 118-128 (2003).

50. Kaiser, K. \& Benner, R. Biochemical composition and size distribution of organic matter at the Pacific and Atlantic time-series stations. Mar. Chem. 113, 63-77 (2009).

51. Hansell, D. A., Carlson, C. A., Repeta, D. J. \& Schlitzer, R. Dissolved organic matter in the ocean. Oceanography 22, 202-211 (2009).

52. Joint, I. et al. Competition for inorganic nutrients between phytoplankton and bacterioplancton in nutriend manipulated mesocosms. Aquat. Microb. Ecol. 29, 145-159 (2002).

53. Marañón, E. Cell size as a key determinant of phytoplankton metabolism and community structure. Ann. Rev. Mar. Sci. 7, 241-264 (2014).

54. Leu, E., Daase, M., Schulz, K. G., Stuhr, A. \& Riebesell, U. Effect of ocean acidification on the fatty acid composition of a natural plankton community. Biogeosciences $(B G)$ 10, 1143-1153 (2013).

55. Anderson, R., Jürgens, K. \& Hansen, P. J. Mixotrophic phytoflagellate bacterivory field measurements strongly biased by standard approaches: A case study. Front. Microbiol. 8, 1398 (2017).

56. Thingstad, T. F. et al. Counterintuitive carbon-to-nutrient coupling in an Arctic pelagic ecosystem. Nature 455, 387 (2008).

57. Bermudez, J. R., Riebesell, U., Larsen, A. \& Winder, M. Ocean acidification reduces transfer of essential biomolecules in a natural plankton community. Sci. Rep. 6, 27749 (2016).

58. Riebesell, U. et al. Technical note: A mobile sea-going mesocosm system-New opportunities for ocean change research. Biogeosciences 10, 1835-1847 (2013).

59. Bellerby, R. G. J. et al. Marine carbonate system evolution during the EPOCA Arctic pelagic ecosystem experiment in the context of simulated Arctic ocean acidification. Biogeosci. Discuss. 9, 15541-15565 (2012).

60. Svalbard Team 2010. EPOCA Svalbard 2010 mesocosm experiment in Kongsfiorden, Svalbard, Norway. (2010). 10.1594/ PANGAEA.769833

61. Dickson, A. G., Sabine, C. L. \& Christian, J. R. Guide to Best Practices for Ocean $\mathrm{CO}_{2}$ Measurements Measurements (North Pacific Marine Science Organization, Sidney, 2007).

62. Lindroth, P. \& Mopper, K. High performance liquid chromatographic determination of subpicomole amounts of amino acids by precolumn fluorescence derivatization with o-phthaldialdehyde. Anal. Chem. 51, 1667-1674 (1979).

63. Dittmar, T., Cherrier, J. \& Ludwichowski, K. The analysis of amino acids in seawater. Pract. Guidel. Anal. Seaw. 67-78 (2009).

64. Engel, A. \& Haendel, N. A novel protocol for determining the concentration and composition of sugars in particulate and in high molecular weight dissolved organic matter (HMW-DOM) in seawater. Mar. Chem. 127(1-4), 180-191 (2011).

\section{Acknowledgements}

We thank all the participants of the Kongsfjorden/Svalbard Mesocosm Experiment 2010 and the Raunefjord/ Bergen Mesocosm Experiment 2011, in particular U. Riebesell, K. Schulz, A. Ludwig, J. Czerny, L. Bach, The KOSMOS team and scientific divers for technical support. We are grateful for support in sampling and sample analysis by A. Paul, J. Roa, R. Flerus, L. Galgani, J. Piontek, C. Borchard and N. Händel. We are also grateful for the insightful comments of two anonymous reviewers. Funding was provided by EU-project EPOCA, BMBFprojects BIOACID and SOPRAN. This is a contribution to the MicroARC project (03F0802A) within the Changing Arctic Ocean program, jointly funded by the UKRI Natural Environment Research Council (NERC) and the German Federal Ministry of Education and Research (BMBF).

\section{Author contributions}

A.E. conceived the idea of biomolecule specific comparison between mesocosm studies simulating ocean acidification. J.G., S.E. and A.E. brainstormed on how to do this. S.E. and A.E. were integral in conducting mesocosm studies. J.G. compiled the dataset and conducted the statistical analysis. J.G. wrote the first draft of the paper. 
S.E. and A.E. edited and commented on the manuscript and contributed to the text and figure presentations in later iterations.

\section{Funding}

Open Access funding enabled and organized by Projekt DEAL.

\section{Competing interests}

The authors declare no competing interests.

\section{Additional information}

Supplementary information is available for this paper at https://doi.org/10.1038/s41598-020-77645-3.

Correspondence and requests for materials should be addressed to J.G.

Reprints and permissions information is available at www.nature.com/reprints.

Publisher's note Springer Nature remains neutral with regard to jurisdictional claims in published maps and institutional affiliations.

(c) (1) Open Access This article is licensed under a Creative Commons Attribution 4.0 International cc) License, which permits use, sharing, adaptation, distribution and reproduction in any medium or format, as long as you give appropriate credit to the original author(s) and the source, provide a link to the Creative Commons licence, and indicate if changes were made. The images or other third party material in this article are included in the article's Creative Commons licence, unless indicated otherwise in a credit line to the material. If material is not included in the article's Creative Commons licence and your intended use is not permitted by statutory regulation or exceeds the permitted use, you will need to obtain permission directly from the copyright holder. To view a copy of this licence, visit http://creativecommons.org/licenses/by/4.0/.

(C) The Author(s) 2020 